\author{
Maryna Derzhevetska \\ PhD of Economics \\ Donetsk National Medical University, Kramatorsk, Ukraine \\ E-mail:marina_d.a@ukr.net \\ ORCID: https://orcid.org/0000-0002-9952-4992 \\ Tamara Kukhtyk \\ Professor, Doctor of Technical Sciences \\ Donbass Institute of Technology and Management Higher Educational Institution \\ "Academician Yuriy Bugay International Scientific and technical university», Kramatorsk, Ukraine \\ E-mail:ditmtvk@icloud.com \\ ORCID: https://orcid.org/0000-0002-2000-3669

\section{Iryna Getman} \\ PhD of Technical Sciences \\ Donbas State Engineering Academy, Kramatorsk, Ukraine \\ E-mail: getman_irina@ukr.net \\ ORCID: https://orcid.org/0000-0003-1835-4256

\section{Olena Khoroshailo} \\ PhD of Pedagogical Sciences \\ Donbass Institute of Technology and Management Higher Educational Institution \\ "Academician Yuriy Bugay International Scientific and technical university", Kramatorsk, Ukraine \\ E-mail: khoroshajlo@gmail.com \\ ORCID: https://orcid.org/0000-0002-4193-6804
}

\title{
Approaches and principles of intellectual capital management at industrial enterprises
}

\begin{abstract}
Despite a large number of studies devoted to the intellectual capital management at industrial enterprises, its structure, evaluation and some issues remain fragmentary. In particular, there is no scientific approach to the interpretation of the content and formation of the intellectual capital structure. The process of transition of management technologies to a new level of SMART enterprises is not fully studied, and the system of rapid assessment of intellectual capital at industrial enterprises and express - management of it in connection with such transition is not considered. The need for further research in this area led us to the choice of the paper topic. The author's definition of the concept of intellectual capital is considered as a set of intellectual potential of people and structural capital, which on the basis of methods of formation, effective management, use and reproduction of intellectual resources (intellectual property and digital industry) is aimed at achieving economic efficiency of the enterprise. The paper considers the most significant approaches to intellectual capital management, highlights the features and advantages of each approach. An effective system of intellectual capital management at industrial enterprises is proposed. For this purpose, we recommend the fundamental requirements for an effective intellectual capital management system of industrial enterprises: the scientific principle, the principles of complexity and consistency, collegiality of decisions made, permanence, innovation principle and informatization. It is the principle of informatization that allows us to monitor the internal and external environment of the enterprise and consider the studied phenomena and factors in dynamics. For the effective implementation of the management system principles, the requirements of efficiency and adaptability, high speed, completeness and reliability are selected, which contribute to the construction of a competitive intellectual capital management system for industrial enterprises.
\end{abstract}

\author{
Keywords \\ Intellectual capital, \\ management system, \\ management principles, \\ informatization principle, \\ information, intellectual \\ capital management
}

JEL: F2, F6

DOI: https://doi.org/10.30525/2500-946X/2021-1-2

\section{Problem statement}

In the context of the global transition from an industrial economy to an intellectual one, significant changes are taking place. The modern era of innovation, in which advanced technologies are rapidly and radically changing the direction of economic sectors development and targets, is called Industry 4.0. In the process of these changes, a completely new type of Management in industrial production is emerging, based on the so-called Big Data (Big Date) and their analysis, full automation of production (cyberphysical systems), augmented reality technologies, and the Internet of Things (IoT). Particular importance in this process belongs to intellectual capital (IC), which significantly affects the industry sectoral structure, quality, manufacturability, innovation of manufactured products and 
services, as well as determines the efficiency of functioning of enterprises. Consequently, the development of intellectual labor and the degree of its participation in industrial processes become the most important factors determining the country's competitiveness in the international market, its export potential and share in the world production.

The transition of the Ukrainian economy to an innovative model, as in most developed countries, is marked by a role decrease of production material factors and an importance increase of information and knowledge as the main production resources, in particular in the machine-building industry. A real understanding and use of the "knowledge economy" can solve most of the financial problems and ensure the dynamic development of Mechanical Engineering.

Today, Ukraine has great potential in the scientific and educational sphere, ranking 47th out of 189 according to the UN education index, it is ahead of such countries as, for example, Brazil (which is considered a "potential superpower", 92th place) and China (which has already been practically realized as an economic and military superpower, 110th place) [1]. Rapid scientific and technological progress has made it possible to change the classical model of landlabor-capital production, which has long been crucial for enterprises (including machine-building ones), adding intellectual resources to it as another important factor for production.

Intellectual resources can be considered as means that allow us to act as a factor of innovative ensuring the industrial enterprises competitiveness.

Analyzing the existing approaches to studying the essence of intellectual resources (accounting, legal, philosophical, etc.), we can say that the most correct of the available ones is the economic approach. It interprets intellectual resources from the point of view of the intellectual capital theory, which the enterprise uses in the producing value process. This transformation and effective intellectual capital management allows you to speed up production processes, identify and disseminate information and experience, create conditions for the knowledge use and transfer within the enterprise, thereby expanding its innovation activities.

However, effective management of an enterprise's intellectual capital is impossible without building an effective structure, the functioning of which is based on progressive and scientifically based principles and approaches.

\section{Purpose of the research}

The purpose of this paper focuses on the analysis of existing approaches to intellectual capital management at industrial enterprises, which leads to the need of creating an intellectual capital managing system at an industrial enterprise using modern information technologies.

\section{Analysis of recent researches and publications}

Domestic and foreign scientists were engaged in intellectual capital management at industrial enterprises. A.V. Kenduukhov believes that today "the contours of intellectual capital as an economic category have already been identified, but the attribution of knowledge alone to intellectual capital significantly narrows the concept, leaving such objects as company customers, trademarks, loyalty, management structure, corporate culture out, which a number of researchers also refer to intellectual capital» [2, p. 33-34]. L.I. Lukicheva compared the process of intellectual capital management with a set of actions and measures aimed at ensuring effective planning, organization and control over the formation processes, development and use of the enterprise resource, as well as motivation for its accumulation and multiplication [3, p. 136]. A.A. Blinov noted that effective intellectual capital management ensures the most effective use of information and knowledge in economic activities; increasing the enterprise market value, securing legal rights on intellectual property objects for their authors; using the intellectual capital of employees; creating a system for protecting intellectual property objects; creating a system for evaluating and accounting for intellectual capital of employees, divisions and the enterprise as a whole [4, p. 193]. Researchers G. Roos, S. Pike, L. Fernstrom understood intellectual capital management as the allocation and use of this capital resources, as well as their management and transformation into traditional economic resources in order to maximize the current value of the organization for stakeholders [5, p. 34]. B. Marr argued that intellectual capital management is complicated by the difficulty of determining the contribution of each of its components, because they are interrelated. This can be explained by the fact that the latest technology is worth little without the knowledge necessary to apply it, and the most recent knowledge and skills about working with new technologies are meaningless if there is no access to these technologies [6, p. 312-315]. I. M. Zelisko justifies the socio-economic feasibility and effectiveness of implementing monitoring of the intellectual capital of an enterprise, suggests applying a qualitative assessment, aspects of measuring and analyzing the effectiveness of using the intellectual capital of an enterprise, which are carried out on the basis of identifying the advantages and disadvantages of currently available diagnostic methods [7]. A.V. Glushko considers intellectual capital as a factor of ensuring the economic stability of a machine-building enterprise [8].

\section{Research results}

Despite the variety of management methods, today a single structure that takes into account all the requirements of the modern information society and allows to prevent all risks in advance and fully realize all the opportunities that arise in the context of the "new economy" has not been developed.

Industry has always been and remains an intensively developed and leading industry in Ukraine. However, do not forget that it requires not only constant modernization of production resources, but also effective management of both the enterprise itself and intellectual capital, which occupies an authoritative place among traditional factors of production.

The goal of an effective intellectual capital management system is to create an integrated approach to the system of evaluating and managing information and knowledge brought to the legal and economic plane.

Various definitions of the effectiveness of intellectual capital management are due to significantly different approaches to this process, in which scientists use many synonymous terms or combine heterogeneous elements. 
The analysis of existing approaches allowed us to group them and identify the following items on which Intellectual Capital Management is based: system, functional, process, structural, innovative, complex, globalized, integration, marketing, situational, quantitative (table 1 ).

When managing intellectual capital of industrial enterprises, the greatest attention should be paid to system and process approaches, where intellectual capital management is considered as a specific function, the implementation of which occurs through principles, general functions, methods and management decisions that act as the starting points for building such system. They take into account the hierarchical levels of the enterprise as an economic system and options for interaction with subjects of the external and internal environment during the formation and development of personnel intelligence and its transformation into products of intellectual activity.

When applying the system approach, we get specifically identified and formed goals, and the goals of individual elements are not a problem for the goals of the entire system, but the external environment can interfere with the functioning of the intellectual capital management system.

However, when using this approach, we have significant drawbacks. It is necessary to build such a system of Intellectual Capital Management, which will be aimed at implementing the following strategic goal to increase the competitiveness and economic efficiency of an industrial enterprise through an innovative breakthrough due to the strengthening and development of intellectual capital, which is possible by applying a process approach to management.

The main features and advantages of the process approach are reducing the number of decision-making levels; delegating authority and responsibility to specific performers; dividing the company's activities into two groups of processes: the system of "suppliers" and "consumers". Suppliers mean input resources and data, equipment, and approaches to performing work that contain logical actions for manufacturing products or providing services. By consumers, we mean persons who use the initial product, which, at the same time, must meet the technological process of its manufacture, and correspond to the requirements

TABLE 1 Approaches to intellectual capital management

\begin{tabular}{|c|c|c|}
\hline № & $\begin{array}{l}\text { Approach, authors } \\
\text { who used it }\end{array}$ & Characteristics of the approach \\
\hline 1 & $\begin{array}{l}\text { System } \\
\text { (O.V. Kendyukhov, } \\
\text { O.E. Kuzmin, } \\
\text { L.I. Lukicheva) }\end{array}$ & $\begin{array}{l}\text { The process of intellectual capital management is presented as an ordered open system, in which elements, internal and } \\
\text { external relations are distinguished, where the main task is to maintain qualitative certainty by moving it from one state } \\
\text { to another. }\end{array}$ \\
\hline 2 & $\begin{array}{l}\text { Functional } \\
\text { (O.E. Kuzmin, } \\
\text { O.V. Kendyukhov, } \\
\text { V.A. Dresvyannikov) }\end{array}$ & $\begin{array}{l}\text { Enterprise IC management is considered as a specific management function. Control functions are the basis for forming } \\
\text { the structure of the control system and the interaction of its components. They characterize the essence of managerial } \\
\text { activity at all stages of management. }\end{array}$ \\
\hline 3 & $\begin{array}{l}\text { Process mode } \\
\text { (O.E. Kuzmin, } \\
\text { R.A. Fatkhudinov) }\end{array}$ & $\begin{array}{l}\text { When using this approach, intellectual capital management is considered as an interrelated process with a continuous } \\
\text { series of actions that contribute to achieving the goals of the enterprise. }\end{array}$ \\
\hline 4 & $\begin{array}{l}\text { Structural } \\
\text { (L.I. Lukicheva) }\end{array}$ & $\begin{array}{l}\text { It is based on determining the significance, priority of factors, methods, principles and other tools in their totality to } \\
\text { establish a rational ratio and increase the validity of resource allocation }\end{array}$ \\
\hline 5 & $\begin{array}{l}\text { Innovative } \\
\text { (C.M. Klimov, } \\
\text { R.A. Fatkhudinov) }\end{array}$ & $\begin{array}{l}\text { The company is focused on activating innovation activities, which contributes to ensuring competitiveness in an } \\
\text { innovative economy. }\end{array}$ \\
\hline 6 & $\begin{array}{l}\text { Complex } \\
\text { (C.M. Klimov) }\end{array}$ & $\begin{array}{l}\text { Taking into account technical, environmental, economic, organizational, social, psychological aspects of management and } \\
\text { their interrelation }\end{array}$ \\
\hline 7 & $\begin{array}{l}\text { Globalizing } \\
\text { (K.-E. Swabi) }\end{array}$ & Focus on the level of the global system, not on the level of the analyzed object \\
\hline 8 & $\begin{array}{l}\text { Integration } \\
\text { (T. Stewart) }\end{array}$ & Strengthening relationships between individual components of the intellectual capital management system at enterprises. \\
\hline 9 & $\begin{array}{l}\text { Marketing } \\
\text { (I.P. Moiseenko) }\end{array}$ & $\begin{array}{l}\text { The approach provides the orientation of the intellectual capital management system to solve various problems for the } \\
\text { consumer }\end{array}$ \\
\hline 10 & $\begin{array}{l}\text { Situational } \\
\text { (R.A. Fatkhudinov) }\end{array}$ & Management focuses on the ability to work in a specific situation, in a specific place, and at a specific time \\
\hline 11 & $\begin{array}{l}\text { Quantitative } \\
\text { (L. Edwinson, } \\
\text { M. Malone) }\end{array}$ & $\begin{array}{l}\text { The approach determines the transformation of qualitative assessments into quantitative ones using research methods for } \\
\text { operations, calculations, statistical methods, expert assessments, and so on }\end{array}$ \\
\hline 12 & $\begin{array}{l}\text { Reproductive } \\
\text { and evolutionary } \\
\text { (C.M. Klimov, } \\
\text { L.I. Lukicheva) }\end{array}$ & $\begin{array}{l}\text { The process of intellectual activity of enterprises is being updated, which leads to meeting a particular market needs with } \\
\text { lower total costs per unit of useful effect }\end{array}$ \\
\hline 13 & $\begin{array}{l}\text { Normative } \\
\text { (R.A. Fatkhudinov, } \\
\text { V.A. Dresvyannikov) }\end{array}$ & $\begin{array}{l}\text { The key idea of the approach is to determine the standards for the formation and development of intellectual capital of } \\
\text { the enterprise }\end{array}$ \\
\hline
\end{tabular}

Source: compiled by the authors on the basis of $[2 ; 3 ; 9 ; 10 ; 11 ; 12 ; 13 ; 14]$ 
of the customer. Also, the main advantages include the combination of the principle of targeted management with group labor organization; widespread use in various spheres of human activity, which reveals causal relationships between the appearance of undesirable situations in production and ways to eliminate them; focusing on ensuring product quality that meets the wishes of specific consumers; significant use of information technologies in management; automation of the technological process of performing business operations.

An effective intellectual capital management system is primarily determined by the company's desire to increase intangible assets, gain competitive advantages in the market, intellectualize and informatize labor activity in the "new economy". And the construction of the system should be based on such basic principles of economic analysis as consistency, complexity, integrity, cyclicity, adaptability.

The analysis of existing management principles allowed us to propose the main principles of industrial enterprise management: scientific, complex and systematic, collegiality of decisions made, permanence, innovation principle and the principle of informatization.

The principle of scientific character is the need for scientific validity of management system building. That is, the management system based on experience and scientifically based provisions, should not contradict the current economic laws, but establish the connection of elements with other structural units of the subject area. Both domestic and foreign experience is taken into account.

The principles of complexity and consistency consist in the necesity to use system analysis in management decisions. Management measures take into account all components of intellectual capital, the company's activities, as well as environmental factors.

Collegiality of decisions made - comparison takes place according to the same indicators and methodology. If this principle is followed, it is possible to compare the results of intellectual capital management with competing enterprises.

The principle of permanence, which is based on a constant and continuous innovation process, consists of continuous research activities due to the dynamism of processes. Constant verification of intellectual capital allows us to reveal trends in the development of intellectual capital in a timely manner and make qualitative adjustments if necessary.

The innovative principle covers scientifically based basic ideas that determine the goals, forms and methods of implementing intellectual capital management, and consists of the modern information technologies use.

It is quite appropriate and necessary to add the principle of informatization to the above list, which allows you to fully monitor the internal and external environment of the enterprise and consider the phenomena and factors under study in dynamics.

It is with the help of this principle that attention is focused on the significance of information at all production levels and the need for information relationships between the elements of the intellectual capital management system that provide conditions for a continuous management process is assumed. Distortion, insufficiency and untimely information leads to a decrease in management efficiency and an increase in risks in the activities of enterprise

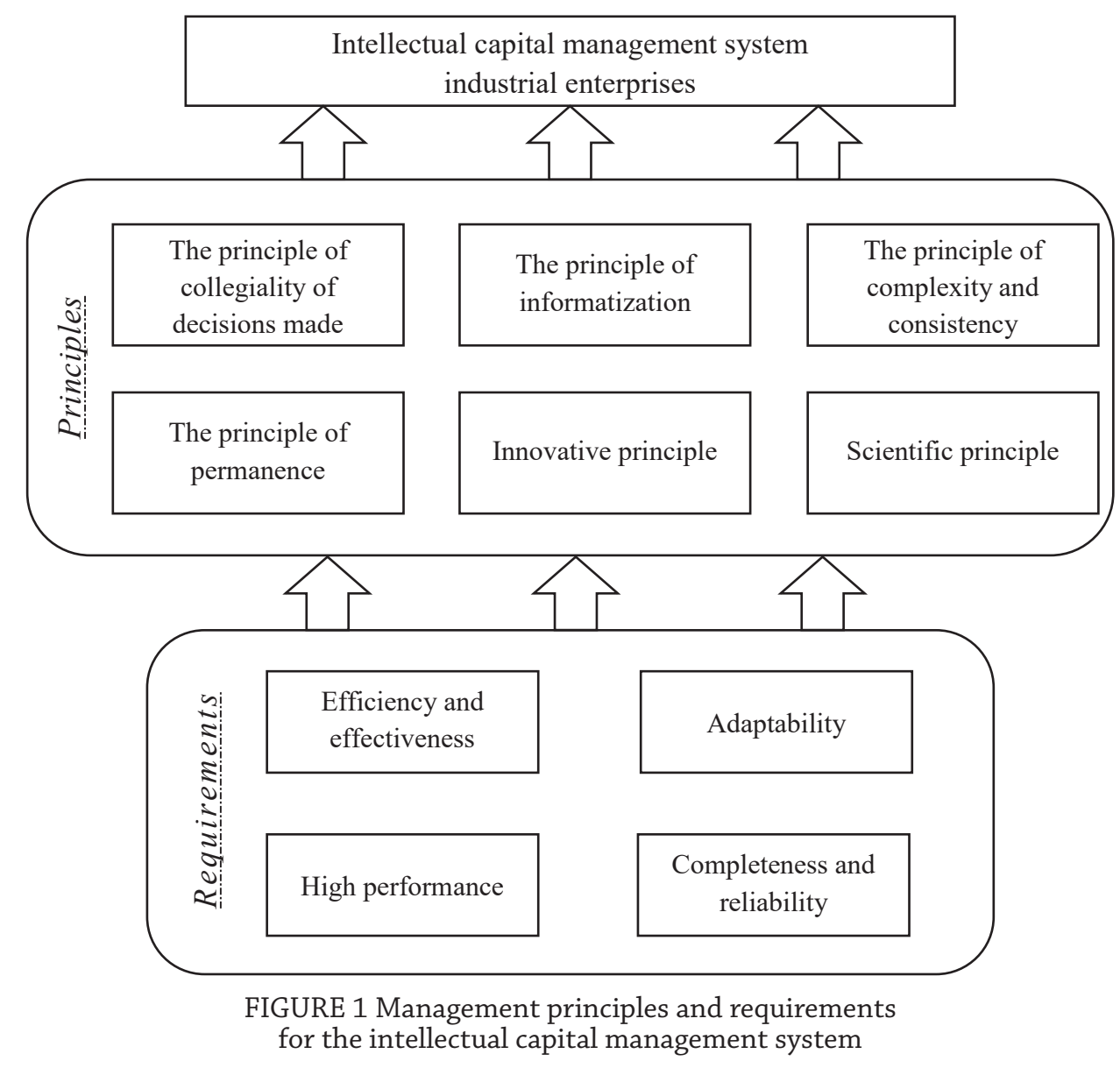


structures, and a deterioration in economic and financial indicators. The more accurate and reliable, complete and useful this information is, the more effective the management will be. A well-established system of informatization of intellectual capital management allows us to fully and reliably characterize the external and internal environment of the Enterprise, their changes, and make the optimal management decision for each specific situation. All this eliminates the state of uncertainty, reduces risks in the activities of enterprises, and ensures their sustainable development.

The principles of intellectual capital management and the requirements for the intellectual capital management system a industrial enterprises are shown in Figure 1.

The main requirements for the intellectual capital management system of an industrial enterprise are the following: efficiency and efficiency from the point of view of the task at hand; adaptability from the point of view of timely and prompt response of the system to changing conditions.

Completeness and reliability of management information are necessary requirements for the implementation of any model, in particular, intellectual capital.

The principle of scientific nature depends on the fullness of information support of the process and requires a lot of processed information.

The high speed of the system will speed up responses to environmental influences. All this led to the need to create a system for intellectual capital managing an industrial enterprise using modern information technologies.

These features allow to build an intellectual capital management system that will help increase the competitiveness of a machine-building enterprise in the market; will lead to an increase in the value of human potential and systematic development of personnel; modernizes business processes; will support management decisions of all management classification forms (financial, strategic, innovative, production).
Intellectual capital management is the ability to create value from intangible assets, a targeted algorithm for converting knowledge into value and innovation. Despite the large number of management approaches, it is quite necessary to improve them. Effective management of intellectual capital contributes to changing the way of thinking of many managers, as well as retreating from outdated approaches and moving to more modern ones, relying on the productivity of a machine-building enterprise and the desire to increase economic indicators.

\section{Conclusion}

The analysis of all existing methods allowed us to conclude that there is no integrated intellectual capital management system for industrial enterprises. However, the need to build such an intellectual capital management system is proved. It will be aimed at implementing the strategic goal of increasing the competitiveness and economic efficiency of an industrial enterprise through an innovative breakthrough due to the strengthening and development of intellectual capital. For such system, it is necessary to define the basic principles of managing an industrial enterprise, in particular its intellectual capital, namely: the scientific principle, the principle of complexity and consistency, the principle of collegiality of decisions made, the principle of permanence, the innovation principle. An additional principle is proposed to highlight the principle of informatization, which focuses on the significance of information at all levels of production and assumes the need for information relationships between elements of the intellectual capital management system that provide conditions for a continuous management process. The main requirements that are characteristic of an effective intellectual capital management system of industrial enterprises are proposed, namely: efficiency and efficiency, adaptability, completeness and reliability, and high system performance. All this led to the need to create a system for managing the intellectual capital at an industrial enterprise using modern information technologies.

\section{References}

[1] Ranking of countries in the world by education level. E-source: http://gtmarket.ru/ratings/education-index/educationindex-info 1 Apr 2021 (in Russian)

[2] Kendyukhov, O. V. (2008). Effective management of intellectual capital Institute of Industrial Economics, National Academy of Sciences of Ukraine: Donetsk, p. 359. (in Ukrainian)

[3] Lukicheva, L. I. (2009). Intellectual Capital Management. Omega-L: Moscow, p. 551. (in Russian)

[4] Blinov, A. O., \& Dresvyannikov, V. A. (2013). Management consulting Publishing and Trade Corporation "Dashkov and $\mathrm{K}^{\circ}$ ": Moscow, p. 212. (in Russian)

[5] Roos, G., Pike, S., \& Fernstrom, L. (2005). Managing Intellectual Capital In Practice Butterworth Heinemann, p. 436.

[6] Marr, B., Schiuma, G., \& Neely, A. (2004). The dynamics of value creation: Mapping your intellectual performance drivers. Journal of Intellectual Capital, 5(2), 312-25.

[7] Zelisko, I. M., \& Ponomarenko, G. Yu. (2015). Management of intellectual capital of enterprises. Kyiv, p. 280. (in Ukrainian)

[8] Glushko, O. V., \& Yaremko, I. Y. (2014). Intellectual capital as a factor in ensuring the economic stability of the machine-building enterprise Management and entrepreneurship in Ukraine: stages of formation and problems of development. Bulletin of the National University "Lviv Polytechnic", 794, 109-14. (in Ukrainian)

[9] Sveiby, K. E. The New Organizational Wealth: Managing and Measuring Knowledge Based. E-source: http://www.sveiby.com/articles/MeasureIntangibleAssets.html 2 Apr 2021

[10] Edwinsson, L. (2005). Corporate Longitude: Navigating the Knowledge Economy INFRA-M: Moscow, p. 247. (in Russian)

[11] Stewart, T. (1998). Intellectual Capital: The new wealth of organization, p. 372-401. (in Russian)

[12] Dresvyannikov, V. A. (2006). Building a knowledge management system at an enterprise KNORUS: Moscow, p. 344. (in Russian)

[13] Fatkhutdinov, R. A. Production management: Textbook for universities. 4th ed. Piter: St. Petersburg, p. 491. (in Russian)

[14] Hilukha, O. A., Kuzmin, O. E., \& Lipich, L. G. (2014). Management of intellectual capital of machine-building enterprises: theoretical and applied provision. Tower-Print: Lutsk, p. 200. (in Ukrainian) 
[15] Getman, M. A. (2016). Definition of intellectual capital in the context of economic-theoretical approach. Scientific works of Donetsk National Technical University: Pokrovsk, 1-2 (18-19), 71-7. (in Ukrainian)

[16] Getman, M. A. (2013). Optimization of the structure of intellectual capital of the enterprise III Starptautiskās jauno pētnieku un studentu zinātniski praktiskās konferences "Izaicinājumu un iespēju laiks: problēmas, risinājumi, perspektīvas”. Rakstu krājumā. Riga: Baltijas Starptautiskā akadēmija, Latvijas, $255-62$. (in Russian)

[17] Getman, M. A. (2017). Analysis of the structure of intellectual capital Journal of the East Ukrainian National University. Vladimir Dahl: Severodonetsk, 6 (236), 75-80. (in Ukrainian)

[18] Derzhevetska, M. A. (2017). Theoretical aspects of intellectual capital. Problems of forecasting and state regulation of socio-economic development (Minsk, Resp. Belarus, 19-20 October 2017), 2, 86-7.

[19] Derzhevetska, M. A. (2017). The role and essence of intellectual capital in modern economic conditions Enterprise economics: modern problems of theory and practice (Odessa, Ukraine, 22-23 September 2017) Atlant: Odessa, 57-8. (in Ukrainian)

[20] Getman, M. A. (2017). Theoretical aspects of intellectual capital of machine-building enterprises VII Starptautiskāsjauno pētnieku un studentu zinātniski praktiskās konferences "Izaicinājumu un iespēju laiks: problēmas, risinājumi, perspektīvas". Rakstu krājumā. (Riga, Latvijas, 11-12 maijs 2017 g.) Baltijas Starptautiskā akadēmija: Riga, 122-5. (in Russian)

[21] Derzhevetska, M. A. (2018). Management of intellectual capital of industrial enterprises (in case of engineering enterprises) The dissertation for the degree of PhD Kramatorsk: Donbass State Engineering Academy of Ministry of Education and Science of Ukraine, 239. (in Ukrainian) 